\title{
KAPAL PERANG JEPANG DI TELUK KOLONO SEBAGAI SUMBER PENINGGALAN SEJARAH (1942-2018) ${ }^{1}$
}

\author{
Oleh \\ Ari Harto ${ }^{2}$, Darnawati
}

\begin{abstract}
ABSTRAK: Subtansi penelitian ini mengacu pada tiga aspek permasalahan dasar: (1) Untuk Menjelaskan latar belakang keberadaan Kapal perang Jepang di Teluk Kolono. (2) Untuk Mendeskripsikan Bagaimana Kondisi Peninggalan Kapal perang Jepangdi Teluk Kolono.(3) Untuk Menjelaskan Bagaimana akibat pendudukan Jepang bagi masyarakat dengan masuknya kapal perang Jepangdi Teluk Kolono.

Metode yang digunakan dalam penelitian ini adalah metode sejarah menurut Helius Sjamsuddin yang terdiri atas: (1) Pengumpulan Sumber, yakni pengumpulan sumber melalui studi kepustakaan, dokumen, pengamatan, dan wawancara (2) Kritik Sumber yakni penilaian data melalui kritik eksternal dan kritik internal (3) Historiografi, yaitu penulisan sejarah melalui penafsiran, penjelasan, dan penyajian.

Hasil penelitian dilapangan menunjukan bahwa: (1) Latar belakang masuknya kapal Jepang di Teluk Kolono yaitu: Untuk melakukan persembunyiaan dari pasukan sekutu Amerika Serikat karena Jepang sedang mengalami kemunduran sehabis dijatuhkannya bom atom di Nagasaki dan Hirosima sehingga ditandainya Jepang mengalami kekalahan dalam perang dunia II, mengakibatkan daerah penjajahan Jepang juga mendapatkan dampaknya, termasuk Indonesia. (2) Kondisi Peninggalan kapal perang Jepang di Teluk Kolono sudah tak utuh lagi, karena tidak dijaga dan dilestarikannya salah satu situs peninggalan sejarah tersebut oleh pemerintah dan masyarakat setempat serta instansi terkait, karena kurangnya pemahaman sejarah dan arti betapa pentingnya peninggalan sejarah sebagai bukti nyata kejadian masa lampau yang harus terus di jaga. Dari kekurangan tersebut mengakibatkan diambilnya besi-besi kapal oleh beberapa oknum masyarakat untuk ditimbang dan dijual demi memenuhi kebutuhan hidup mereka seharihari .(3) Akibat pendudukan Jepang dengan masuknya kapal perang Jepang di Teluk Kolono yakni: tidak berjalan normalnya kehidupan masyarakat dan banyak aktivitas dan rutinitas yang terganggu dikarenakan takutnya masyarakat terhadap penjajah Jepang yang masuk di Teluk Kolono, seperti aktivitas mencari ikan di laut, serta aktivitas-aktivitas lainya, begitupula dengan masuknya kapal perang Jepang di Teluk Kolono serta dibomnya kapal tersebut memiliki dampak berarti yakni masyarakat tidak dapat memakan ikan dengan waktu berbulan-bulan serta tidak dapat mengambil air di kali sena dikarenakan banyak mayat di perairan Teluk Kolono.
\end{abstract}

\section{Kata Kunci: Kapal Perang, Jepang, di Teluk Kolono}

\footnotetext{
${ }^{1}$ Disandur dari hati penelitian

${ }^{2}$ Alumni Jurusan Pendidikan Sejarah

${ }^{3}$ Dosen FKIP UHO
} 


\section{PENDAHULUAN}

Indonesia merupakan negara dengan mempunyai sejarah panjang.Dari berbagai peristiwa sejarah yang terjadi salah satunya penjajahan, tercatat yang menjajah Indonesia yakni Belanda dan Jepang.Belanda yang menjajah Indonesia kurang lebih 350 tahun harus berakhir di karenakan mengalami kekalahan terhadap Jepang.Selanjutnya Jepang yang menjajah Indonesia namun penjajahan Jepang terbilang begitu singkat yakni terhitung dari tahun 1942 sampai berakhir 17 agustus 1945.

Daerah Sulawesi dikuasai Jepang melalui sisi utara yakni setelah Jepang menguasai wilayah Philipina dan sekitarnya, Philipina oleh Jepang dijadikan sebagai daerah awal untuk menyerang wilayah Indonesia, termasuk juga Pulau Sulawesi. Penyerbuan di maksudkan Jepang untuk mengejar tentara Hindia Belanda yang bertugas di Sulawesi Utara, Sulawesi Tengah, Sulawesi Selatan dan Sulawesi Tenggara (Melamba, 2013: 362).

Pemimpin Jepang menyadari bahwa kemenangan hanya dapat dicapai dengan bantuan sepenuhnya dari rakyat Indonesia.Bantuan ini tidak hanya bantuan moral, tetapi juga bantuan material dan tenaga.Dengan demikian maka secara maksimal, Jepang mengarahkan semua rakyat dalam usahanya memenangkan perang.Sainenden (barisan pemuda) mengorganisir pemuda, dengan tujuan untuk memperoleh bantuan pengamanan kampung dan mengerakkan gotong-royong dalam usaha meningkatkan atau mempertahankan perekonomian rakyat dikampung-kampung.Dalam memperoleh bantuan tenaga militer, pemudah yang tangguh dipilih untuk dijadikan Haiho atau Kaigun dengan memberikan latihan berat.Di bidang produksi untuk konsumen ekspor yang amat dibutuhkan adalah produksi massal dalam waktu singkat. Disamping itu, Jepang juga membutuhkan tenaga rakyat secara maksimal. Demikian pula dalam pembangunan jalan, lapangan terbang dan kubu-kubu pertahanan dan perlindungan Jepang juga membutuhkan tenaga yang besar pula (Anwar Hafid, Misran Safar, 2007: 99-100).

Jepang yang berhasil menguasai daerah Sulawesi khususnya Sulawesi Tenggara, membuat mereka berkuasa sepenuhnya dan dijadikannya Sulawesi Tenggara sebagai pangkalan militer mereka.Dengan itu, Jepang meninggalkan banyak peningalanpeninggalnya, baik bungker, goa dan meriam dll. Dengan daerah yang strategis dan memiliki banyak pulau tentu menjadi keuntungan buat Jepang. Disisi lain dengan terbatasnya pangkalan udara yang tidak ada di tiap-tiap pualu itu, secara otomatis jepang menggunakan transportasi laut, yang tidak lain menggunakan kapal, utuk memuat berbagai macam kebutuhan perang, misalnya bom, meriam, peluruh, dan uang koin sekalipun.

Pada masa kependudukan Jepang dibidang pemerintahan umum tidak banyak mengalami perubahan hanya disesuaikan dengan pemerintahan pendudukan militer Jepang. Untuk memudahkan pengawasan wilayah Indonesia dibagi kedalam tiga pengawasan pemerintahan yaitu (1) pemerintahan militer angkatan darat tentara ke enam belas meliputi pulau Jawa dan Madura berkedudukan di Jakarta, (2) pemerintahan militer angkatan darat tentara kedua puluh lima meliputi Sumatra berkedudukan di Bukittinggi, dan (3) pemerintahan militerangkatan laut armada selatan kedua meliputi Kalimantan, Sulawesi, Nusa Tenggara, Maluku dan Irian Jaya berkedudukan di Makassar. (Tamburaka, 2004:323).

\section{METODE PENELITIAN}

Penelitian ini telah dilakukan di Kecamatan Kolono dan Kecamatan Kolono Timur Kabupaten Konawe Selatan. Penelitian yang dilakukan ini adalah jenis penelitian sejarah, dengan menggunakan pendekatan peristiwa yang dilakukan dengan cara mengumpulkan 
data, mengevaluasi, menganalisa fakta sejarah secara objektif dan sistematis dalam mendapatkan kesimpulan yang diperoleh melalui pendekatan deskriptif kualitatif yaitu pendekatan dengan mengumpulkan data atau fakta sebanyak-banyaknya kemudian dianalisa secara kualitatif.

Sumber data dalam penelitian ini dapat diklasifikasikan menjadi tiga yaitu: (1) Sumber lisan diperoleh melalui keterangan dari wawancara dengan paratokoh masyarakat, serta orang yang mengetahui tentang masalah yang diteliti., (2) Sumber benda atau sumber visual, yaitu data yang diperoleh melalui hasil pengamatan terhadap lokasi penelitian yaitu berupa benda peninggalan sejarah kapal perang Jepang di Teluk Kolono., (3) Sumber tertulis diperoleh dalam bentuk tulisan seperti buku, skripsi dan laporan penelitian terdahulu, maupun internet yang ada relevansinya dengan penelitian yang dilakukan ini.

Adapun langkah penelitian ini sesuai dengan yang ditulis Helius Sjamsudin (2012: 67-121) yaitu heuristik, kritik sumber, historiografi, dengan tata kerja sebagai berikut: (1) Heuristik (Pengumpulan Sumber), (2) Kritik sumber, (3) Historiografi.

\section{HASIL PENELITIAN DAN PEMBAHASAN}

\section{Latar Belakang Datangnya Kapal Perang Jepang di Teluk Kolono}

Jepang yang merupakan salah satu negara Asia pertama yang menjadi negara Imperialisme dan menjadi negara industri akan melakukan apapun untuk memenuhi kebutuhan industrinya, olehnya itu sebagai negara Industri yang membutuhkan segala bentuk bahan-bahan industrinya, mereka melakukan penjajahan terhadap negara yang mempunyai kekayaan alam yang melimpah untuk memenuhi segala keperluan industrinya dan Jepang berusaha mengeruk habis segala kekayaan alam negara yang mereka kuasai.

Dengan mendaratnya Jepang di Indonesia pada Januari 1942 di Ambon menjadi tanda imperialisme Jepang dimulai di Indonesia, dan menjadi awal aktivitas mengeksploitasi Indonesia disegala bidang, walaupun dengan masuknya Jepang itu tidak serta merta berjalan mulus, melainkan terus mendapat perlawanan terhadapap imperialis Belanda yang pada saat itu sedeng menguasai wilayah Indonesia. Namun, dengan kekuatan Jepang yang kuat yang dilengkapi persenjataan yang lengkap dan canggih dan juga mendapat dukungan oleh masyarakat Indonesia dikarenakan Jepang banyak membujuk rakyat Indonesia agar terlepas dari penjajahan Belanda, sehingga usaha mereka untuk menguasai wilayah-wilayah Indonesia tak bisa terbendung, sehinggah terus masuk sampai wilayah Sulawesi.

Pendudukan Jepang yang merupakan pendudukan pemerintahan militer otomatis segala aktivitasnya adalah adalah tentang pereng karena, dan dengan situasi yang ada pada saat itu yakni, Jepang yang masih berada dalam perlawanan bangsa-bangsa sektu Amerika Serikat, Inggris dan Belanda dan keinginan Jepang untuk meguasai daerah Asia Teggara dan memerlukan segela bahan-bahan industri untuk kebutuhan Industri negara Jepang. Kondisi pada saat itu yang mereka inginkan adalah menguasai Asia Tenggara, Indonesia pada khususnya yang mana mempunyai sumber daya alam yang melimpah dan menjadi sasaran negara-negara imperialisme untuk menguasai bangsa Indonesia., dengan melimpahnya sumber daya alam Indonesia membuat kebutuhan Jepang bisa terpenuhi, dikarenakan Jepang merupakan negara industri. Dilain sisi dapat dilihat dengan pendudukan oleh negara-negera penjaja khususnya Jepang di Indonesia banyak menimbulkan kesengsaraan oleh rakyat, karena bukan hanya Jepang melakukan pendudukan atau penguasaan terhadap wilayah Indonesia melainkan mereka juga 
mengeksploitasi tenaga para penduduk Indonesia guna menjalankan segala bentuk punya strategi terhadap perlawananan musuh.

Kapal perang Jepang sendiri masuk di Teluk Kolono dengan tujuan bersembunyi dari intaian pasukan pesawat sekutu Amerika Serikat yang pada saat itu menjadi sasaran pencarian pasukan sekutu Amerika Serikat, yang mana Jepang telah mengalami masa-masa sulit setelah kalah dalam perang dengan pasukan sekutu oleh Amerika Serikat bersama Inggris dan Belanda pada tanggal 14 Agustus serta dijatuhkannya bom atom di Nagasaki dan Hirosima 1945.

Hal ini senada apa yang disampaikan oleh bapak Happing, sebagai saksi dan pelaku sejarah pribumi ketika datanganya kapal perang Jepang. Yang mana ia mengatakan bahwa kapal Perang Jepang sendiri masuk di Teluk Kolono setelah dijatuhkannya bom atom di Nagasaki dan Hirosima, tujuan masuknya sendiri guna bersembunyi dari pasukan Amerika Serikat, yang mana pada saat masuknya kapal Jepang, pihak jepang menyuruh masyarakat setempat untuk mengambilkan kelapa dan daun kelapa untuk dijadikan penutup kapal, yang pada saat itu pesawat Amerika Serikat yang berjumlah 6 sedang berpatroli di udara Sulawesi Tenggara dan juga perairan teluk Kolono. (Wawancara, 25 Agustus 2018).

\section{Kondisi Peninggalan Sejarah Kapal Perang Jepang di Teluk Kolono}

Sebagai negara yang pernah dijajah oleh bangsa lain, seperti Belanda dan Jepang, Indonesia memiliki banyak peninggalan-peninggalan sejarah bangsa lain, seperti goa, meriam, bom dan sebagainya, namun dengan segala jenis peninggalan yang ada di Indonesia, banyak situs peninggalan-peninggalan Sejarah yang masih dilestarikan atau dijaga dan banyak pula situs peninggalan yang belum terlestarikan atau dijaga. Akibat tidak dijaganya situs-situs peninggalan sejarah tersebut oleh pemerintah dan masih kurangnya pemahaman pada masyarakat Indonesia terhadap pentingnya peniggalanpeniggalan sejarah untuk menjadikan pelajaran kepada bangsa Indonesia dan kepada peserta didik Indonesia.

Bukti keberadaan penjajahan Jepang di Indonesia pada masa perang Dunia II sampai saat ini masih banyak ditemukan hampir di seluruh kawasan di Indonesia. Bukti keberadaan penjajahan Jepang yang dimaksud adalah bukti berupa tinggalan budaya material yang dapat berupa bangunan sarana militer Jepang seperti bangunan bunker, pillbox, gua-gua atau terowongan bawah tanah, serta landasan pesawat udara yang lengkap dengan berbagai macam instalasi militernya dan kapal-kapal Jepang yang karam diseluruh perairan Indonesia. Terkait dengan keberadaan sisa-sisa peninggalan kebudayan material di Indonesia.Terkhusus peninggalan kebudayaan material Jepang masa Perang Dunia II di Indonesia pada umumnya belum mendapatkan perhatian yang khusus dari berbagai pihak terutama masyarakat. Secara umum masyarakat kita masih awam dan juga masih belum memahami sepenuhnya akan betapa pentingnya tinggalan-tinggalan tersebut yang seharus perlu dirawat dan dijaga dengan baik..

Kapal perang Jepang yang ada di teluk Kolono merupakan salah satu peninggalan Imperialisme bangsa Jepang yang tak dilestaiakan dan dijaga, sehingga menjadikan peninggalan sejarah tersebut berkurang dengan diambilnya sebagian besar bangkai kapal tersebut oleh para pekerja-pekerja kapal untuk ditimbang dan dijual demi memenuhi kebutuhan mereka. Meski saat ini kapal perang Jepang tersebut tidak lagi utuh dan terlihat di permukaan laut teluk Kolono, namun di kawasan dasar laut tersebut masih ditemukan sisa-sisa bangkai kapal tersebut.Seperti peninggalan Jepang lainnya yang dibangun sebagai sarana pendukung dan penunjang segala aktifitas militer mereka, Sarana-sarana pendukung 
dan penunjang aktifitas militer Jepang tersebut yang dapat disebutkan disini diantaranya adalah pillbox, terowongan bawah tanah, meriam.kapal perang Jepang merupakan saran pendukung dan juga memiliki peran yang sangat penting yakni, sebagai alat transportasi untuk memuat alat-alat perang dan juga para tenaga romusha untuk melancarkan segala bentuk rencana Jepang dalam menghadapi peperangan dengan pasukan Sekutu Amerika Serikat.

Kapal perang Jepang masuk diteluk Kolono sore hari sekitar Jam 5 sore masih dalam keadaan utuh dan bagus, namun setelah mereka masuk di dalam teluk Kolono dan menyuruh warga disekitaran desa Puupi untuk mengambil daun kelapa dan kelapa, mereka kembali untuk keluar dari wilayah teluk Kolono, seketika dalam perjalanan mereka mengetahui ada pasukan sekutu sedang berpatroli mereka singgah di mulut teluk Kolono, di malam harinya pesawat dari pasukan sekutu Amerika Serikat yang masih berpatroli di wilayah Sulawesi Tenggara, dan wilayah teluk Kolono tidak menjatuhkan bom deluan melaikan pihak tentara Jepang yang berada di kapal yang menyenter pesawat Sekutu Amerika dan menembaknya, dan tembakaan pihak Jepang ke pesawat sekutu tak mengenainya, sehingga pihak Jepang mendapat balasan dari pasukan sekutu dengan kembalinya Pesawat sekutu Amerika diatas wilayah perairan teluk Kolono dan mereka berputar-putar dan menjatuhkan bom ke kapal Jepang berkali-kali sekitar jam 8 sampai 9 malam, sehingga kapal tersebut terkena. Dengan dijatuhkanya bom pasukan sekutu, masyarakat Kolono merasakan getaran yang luar biasa dengan jatuhnya bom tersebut, dan dengan dijatuhkannya bom oleh pasukan sekutu dimalam hari masyarakat kolono seketika terkejut yang melihat wilayah perairan teluk Kolono kemerah-merahan akibat terbakarnya kapal Jepang tersebut. (Happing, Wawancara, 25 Agustus 2018).

Ketika dijatuhkannya bom di kapal Jepang oleh pasukan sekutu selain banyak memuat alat-alat perang Jepang juga diperkirakan dalam kapal tersebut, selain para tentara Jepang dan awak kapalnya, ada ratusan orang para pekerja romusha yang berada di dalam kapal tersebut. Ini di perkuat dengan cerita turun temurun di sebagian masyarakat Kolono bahwa ketika terjadi pengeboman oleh pasukan sekutu Amerika Serikat, wilayah laut dan pinggir pantai teluk Kolono itu dipenuhi oleh jasad-jasad mayat dari kapal Jepang yang dijatuhkan bom tersebut, dan mayat-mayat tersebut tidak mencirikan orang Jepang, tapi justru mencirikan ras orang Indonesia itu sendiri.

\section{Akibat Pendudukan Jepang Bagi Masyarakat Dengan Masuknya Kapal Perang Jepang Di Teluk Kolono}

Setiap penjajahan yang terjadi di dunia ini memiliki akibat, baik itu memiliki dampak akibat yang negatif maupun berdampak positif, secara umum pendudukan yang dilakukan oleh bangsa imperialis memiliki tujuan dan manfaat bagi negara penjajah itu sendiri. Apa yang dilakukan Belanda kepada Indonesia dengan menjajah dan mengeruk segala bentuk kekayaan sumber daya alam Indonesia kurang lebih 350 tahun banyak memiliki dampak negatif bagi rakyat Indonesia, begitupun dengan Jepang yang menjajah Indonesia kurang lebih hanya tiga setengah tahun, banyak memiliki dampak negatif bagi penduduk Indonesia. Dengan waktu tiga setengah tahun itu, tak membuat Jepang sedikit memperoleh keuntungan dari bangsa Indonesia, bahkan dengan waktu yang singkat itu sedikit banyaknya mampu memenuhi kebutuhan industri mereka

Dengan masuknya kapal Jepang di teluk Kolono, memiliki dampak bagi masyarakat, di karenakan pada saat itu Jepang yang sedang menguasai Indonesia dan wilayah Kendari dan Konawe pada khususnya.Awal datangnya kapal jepang di wilayah 
perairan teluk Kolono membuat masyarakat takut dikarenakan warga mengetahui bahwa Jepang sedang menjajah dan juga melakukan yang namanya kerja paksa (Romusa) mereka takut jika mereka diambil dan jadikan pekerja paksa untuk memenuhi segala kebutuhan perang Jepang.Pihak Jepang hanya meminta kepada masyarakat untuk mengambilkan daun kelapa dan kelapa untuk menutupi kapal Jepang.

Hal ini di amini oleh beberapa cerita diberbagai Informan di masyarakat yang peneliti dapatkan, termaksud bapak Happing yang merupakan saksi dan juga pelaku sejarah terhadap masuknya kapal Jepang, menurut keterangan yang disampaikan bahwa ia dan bapak beliau yang tinggal di desa Puupi mengantarkan kelapa kepada pihak Jepang yang berada di teluk Kolono di bagian kaluku dongga sebutan masyarakat Kolono, bapak Happing dan orang tua beliau memakai perahu dan membawa kelapa tersebut ke kapal Jepang, ia juga menyebutkan bahwa meraka diberi upah oleh pihak Jepang yakni beberap uang koin, dan bahasa yang mereka gunakan hanya bahasa isyarat, tidak hanya itu, penjelasan beliu juga mengatakan bahwa warga masyarakat Puupi yang nota bene adalah suku bajo yang memang mempunyai tradisi tinggal di pinggir laut, di perintahkan oleh Jepang untuk mengambil daun kelapa sebanyak-banyaknya, untuk digunakan menutup kapal Jepang untuk menghidari atau mengelabuhi pasukan sekutu. (Wawancara, 25 Agustus 2018)

Sesuai apa yang dikatakan salah satu sumber yakni Wekona, bahwa, dengan masuknya kapal perang Jepang di teluk Kolono kehidupan masyarakat tidak lagi berjalan normal dengan masuknya kapal tersebut, bahkan lebih parahnya lagi ketika dibomnya kapal tersebut oleh pasukan sekutu Amerika Serikat. Dengan dibomnya kapal perang Jepang oleh pasukan sekutu Amerika serikat, Inggris dan Belanda, masarakat merasakan getaran akibat dijatuhkannya bom tersebut, dan dengan begitu orang-orang yang berada dikapal itu mati, dan mayat mereka terdampar di disepanjang pinggir-pinggir pantai teluk Kolono, bahkan salah satu sumber kehiduapan masyarakat Kolono yang berada di Sena (Sekarang Awunio) yakni air untuk kehidupan sehari-hari tidak mengambil lagi diakbatkan banyak mayat dikali sena yang terbawa oleh air laut yang pasang. mereka mengambil air dikali Sena percampuran air tawar dan air asin yang berada di desa Awunio untuk memenuhi salah satu kebutuhan mereka namun, dengan banyaknya mayat yang terdampar di pinggir pantai teluk kolono, mereka tak menggunakan air dikali tersebut berbulan-bulan, diakibatkan ketika air laut pasang, mayat-mayat tersebut seringkali terikut air laut masuk kekali sena, mereka mengambil air ketika air surut saja, sehingga masyarakat menggunakannya hanya ketika air surut saja, tidak hanya itu masyarakat begitu lama juga tidak memakan ikan dikarenakan takut akibat mayat-mayat tersebut. (Wawancara, 7 Juli 2018).

\section{KESIMPULAN}

Berdasarkan uraian dan pembahasan hasil penelitian, maka penulis dapat menarik kesimpulan yaitu sebagai berikut: pertama masuknya kapal Jepang diteluk Kolono yakni guna melakukan persembunyian dari pasukan sekutu Amerika Serikat, Inggris dan Belanda. Jepang melakukan persebunyian dikarenakan pada saat itu Jepang telah megalami masa-masa sulit dikarenakan Jepang telah mengalami kekalahan dalam perang dunia II, sehingga wilayah kekuasaan Jepang di Indonesia juga menjadi menjadi terancam dari serangan pasukan sekutu. Maka dari itu, Jepang telah mengantisipasi semua itu, sehingga dengan taunya Jepang adanya pasukan sekutu diwilayah Sulawesi, atau daerah Sulawesi Tenggara pada khsusunya menjadikan mereka terus mengantisipasi terhadap pasukan 
Sekutu Amerika Serikat, salah satunya dengan masuk diteluk Kolono untuk menghindar dan bersembunyi dari serangan pasukan sekutu. Kedua kondisi peninggalan kapal perang Jepang di Kolono yang tidak utuh lagi, disebabkan banyak fakor yakni, (a). Faktor masyarakat yang kurang memahami sejarah dan tidak menegerti betapa pentingnya situssitus sejarah bagi daerah, para pelajar dan para peneliti untuk diteliti, agar menjadi tau bagaimana sejarah daerahnya. (b). Faktor Pemerintah, pada umumnya di Indonesia para birokrasi masih banyak yang tidak memperhatikan dan merawat serta melestarikan berbagai peninggalan-peninggalan situs sejarah,sehingga dengan alasan membangun infrastruktur berbagai situs-situs tersebut dihancurkan, begitupun dengan masyarakat, dengan untuk memenuhi kehidupan mereka, peninggalan-peninggalan situs serjarah tersebut di ambil dan dijual, itulah yang terjadi terhadap peninggalan kapal perang Jepang di teluk Kolono. Termasuk Pemerintahan kecamatan Kolono dan Kolono timur yang masih kurang perhatiannya terhadap situs-situs peninggalan sejarah. Tiga dampak pendudukan Jepang dan masuknya Kapal perang Jepang di teluk Kolono membawa dampak yang berarti, diakibatkan ketika masuknya kapal Jepang di teluk Kolono proses kehidupan sosial makin tertekan dikarenakan masyarkat diperintahkan oleh pihak Jepang untuk mengambil daun kelapa dan kelapa untuk menutupi kapal mereka untuk persembunyian pasukan sekutu, dan juga ketika dibomnya kapal Jepang oleh pasukan sekutu Amerika Serikat mengakibatkan massyarakat merasakan getaran yang sangat dahsyat dikarenakan bom yang dijatuhkan ke kapal Jepang berdaya ledak tinggi, disisi lain masyarakat berbulanbulan tidak memakan Ikan dari laut dikarenakan banyak mayat yang terapung dan terdampar di perairan dan pinggir teluk Kolono, dan juga masyarakat daerah Sena (sekarang desa Awunio) tidak bisa menggunakan air dari kali sena sepuas-puasnya untuk kehiduan sehari-hari dikarenakan ketika air pasang maka biasa mayat dari laut terikut ke kali sena, yang kali sena merupakan kali pertemuan atau percampuran air laut dan air tawar.

\section{DAFTAR PUSTAKA}

Basrin Melamba. 2013. Tolaki Sejarah, Identitas dan Kebudayaan. Yogyakarta: Yukita Anwar Hafid, Misran Safar. 2007. Sejarah Kota Kendari. Humaniora: Bandung.

Rustam Tamburaka E dkk. 2004. Sejarah Sulawesi Tenggara dan 40 Tahun Sultra membangun. Universitas Halu Oleo Kerjasama Pemerintah Sulawesi Tenggara.

Helius Samsuddin. 2012. Metodologi Sejarah.Yogyakarta : Ombak 